Article

\title{
Two Supramolecular Cobalt(II) Complexes: Syntheses, Crystal Structures, Spectroscopic Behaviors, and Counter Anion Effects
}

\author{
Hao-Ran Jia, Jing Li, Yin-Xia Sun *, Jian-Qiang Guo, Bin Yu, Na Wen and Li Xu \\ School of Chemical and Biological Engineering, Lanzhou Jiaotong University, Lanzhou 730070, China; \\ jiahr12@163.com (H.-R.J.); iclijing1@163.com (J.L.); sunyinxia198025@126.com (J.-Q.G.); \\ sunyinxia@mail.lzjtu.cn (B.Y.); ic31001@163.com (N.W.); xuli@mail.lzjtu.cn (L.X.) \\ * Correspondence: sun_yinxia@163.com \\ Academic Editor: Shujun Zhang \\ Received: 5 July 2017; Accepted: 30 July 2017; Published: 9 August 2017
}

\begin{abstract}
Two new $\mathrm{Co}(\mathrm{II})$ complexes, $\left[\{\mathrm{Co}(\mathrm{L})\}_{2}\left\{\mathrm{Co}(\mathrm{Pic})_{2}\left(\mathrm{CH}_{3} \mathrm{OH}\right)_{2}\right\}\right](\mathbf{1})$ and $\left[\{\mathrm{CoL}(\mu-\mathrm{OAc})\}_{2} \mathrm{Co}\right](\mathbf{2})$, where $\mathrm{H}_{2} \mathrm{~L}=2,2^{\prime}$-[Ethylenedioxybis(nitrilomethylidyne)]dinaphthol, were designed, synthesized and characterized by elemental analysis, FT-IR spectra, UV-Vis spectra, and X-ray crystallography. Complex 1 consists of two [CoL] and one $\left[\mathrm{Co}(\mathrm{Pic})_{2}\left(\mathrm{CH}_{3} \mathrm{OH}\right)_{2}\right](\mathrm{Pic}=$ picrate) units and in the [CoL] unit, the $\mathrm{Co}(\mathrm{II})$ atom is tetra-coordinated with a slightly distorted square-planar geometry. In the $\left[\mathrm{Co}(\mathrm{Pic})_{2}\left(\mathrm{CH}_{3} \mathrm{OH}\right)_{2}\right]$ unit, the $\mathrm{Co}(\mathrm{II})$ atom is hexa-coordinated with a slightly distorted octahedral geometry. Meanwhile in complex 2, two acetate ions coordinate to three $\mathrm{Co}$ (II) atoms through Co-O-C-O-Co bridges and four $\mu$-naphthoxo oxygen atoms from two [CoL] units also coordinated to the central $\mathrm{Co}(\mathrm{II})$ atom. Thus, complex 2 has two distorted square pyramidal coordination geometries around the terminal $\mathrm{Co}$ (II) atom and an octahedral geometry around the central $\mathrm{Co}$ (II) atom. The supramolecular structures of complex 1 is a 3D-network supramolecular structure linked by $\mathrm{C}-\mathrm{H} \cdots \mathrm{O}$ hydrogen bonds and $\pi \cdots \pi$ stacking interaction, but complex 2 possesses a self-assembled 2D-layer supramolecular structure linked by C-H $\cdots \pi$ and $\pi \cdots \pi$ stacking interactions. The structure determinations show that the coordination anions are important factors influencing the crystalline array.
\end{abstract}

Keywords: Co(II) complex; Salamo-type ligand; synthesis; crystal structure; supramolecular interaction; anion effects

\section{Introduction}

Salen-type compounds or their derivatives have received much attention not only because of their versatile architectures and topologies tuned by metal ions and organic ligands [1-5], but also due to their properties for potential applications in various areas, such as catalysis [6], bioscience [7-10], host-guest chemistry [11-14], electrochemistry [15,16], magnetism [17-21], optical properties [22-28], and molecular recognition [22,23,29,30]. More and more research programs have focused on the syntheses of Salamo-type complexes by the structural motifs of substituent groups in recent years [31-33], because the Salamo compounds are more stable than the Salen compounds [34]. The Salamo-type $\mathrm{N}_{2} \mathrm{O}_{2}$ ligands can easily coordinate with several different types of transition metal ions in a tetradentate fashion to obtain stable mononuclear, multinuclear and hetero-polynuclear complexes which have novel structures and excellent capabilities [35-37], such as, recognition of metal cations, used as stereochemical catalysts, and to serve as optoelectronic materials.

There are many important factors, such as the metal ions, ligands, counter anions or coordination anions, temperatures, $\mathrm{pH}$ values, and solvents [38-45], which always have a major influence on the 
construction of the coordination compounds. Among the groups that can be coordinated with metal ions, apart from ligands, the coordination anion is one of the direct and obvious factors. In order to further study the influencing factors on complex structures in the process of constructing metal complexes with the Salamo ligands, we designed and synthesized a Salamo ligands $\mathrm{H}_{2} \mathrm{~L}$ (Scheme 1) and its two novel Co(II) complexes. The structures and spectral properties were studied. The results presented herein indicate that the coordination anions have a significant influence on the structures of the resulting complexes.

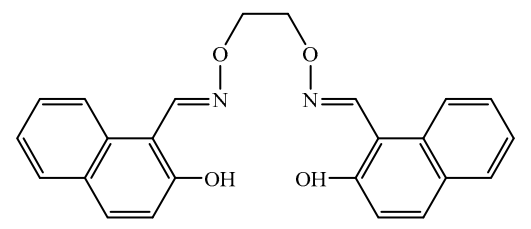

Scheme 1. Chemical structure of the ligand $\mathrm{H}_{2} \mathrm{~L}$.

\section{Experimental}

\subsection{Reagents and Physical Measurements}

Commercially available 2-hydroxynaphthaldehyde was purchased from Aladdin Chemistry (Aladdin, Shanghai, China), and other solvents from Tianjin Chemical Reagent Factory (Tianjin, China) were analytical grade, which were used without further purification. $\mathrm{C}, \mathrm{H}$, and $\mathrm{N}$ analyses were performed with a GmbH VariuoEL V3.00 automatic elemental analyzer. ${ }^{1} \mathrm{H}$ NMR spectra were measured at room temperature in $\mathrm{CDCl}_{3}$ solution on a Bruker 400 instrument recording at $400 \mathrm{MHz}$ frequency. FT-IR spectra were recorded on a VERTEX70 FT-IR spectrophotometer, with samples prepared as $\mathrm{KBr}\left(400-4000 \mathrm{~cm}^{-1}\right)$ and CsI $\left(100-500 \mathrm{~cm}^{-1}\right)$ pellets. UV-Vis absorption spectra were determined on a Shimadzu UV-2550 spectrometer (Shimadzu, Tokyo, Japan). X-ray single crystal structures were obtained on a Rapid Auto Version 3.0 Rigaku RAXIS-RAPID detector. The melting points were determined by a micromelting point apparatus produced by BEIJING TAIKE INSTRUMENT CO., LTD. (Beijing, China).

\subsection{Synthesis of $\mathrm{H}_{2} \mathrm{~L}$}

The compound 1,2-bis(aminooxy)ethane was synthesized by a similar method to that reported previously $[46,47]$ and 2,2'-[ethylenedioxybis(nitrilo-methylidyne)]dinaphthol $\left(\mathrm{H}_{2} \mathrm{~L}\right)$ was synthesized according to an analogous method reported previously in the literature [48,49]. A methanolic solution $(20 \mathrm{~mL})$ of 1,2-bis(aminooxy)ethane $(92.1 \mathrm{mg}, 1.0 \mathrm{mmol})$ was added to a solution of 2-hydroxynaphthaldehyde (349.5 mg, $2.02 \mathrm{mmol})$ in ethanol $(20 \mathrm{~mL})$ and the mixture was stirred at $55{ }^{\circ} \mathrm{C}$ for $4 \mathrm{~h}$. Then the solvent was removed under reduced pressure and the residue was recrystallized from ethanol to give the ligand $\mathrm{H}_{2} \mathrm{~L}(897.5 \mathrm{mg}, 56.5 \%)$. M.p. $157-158{ }^{\circ} \mathrm{C}$. Anal. Calcd for $\mathrm{C}_{24} \mathrm{H}_{20} \mathrm{~N}_{2} \mathrm{O}_{4}(\%)$ : C, 71.99; $\mathrm{H}, 5.03 ; \mathrm{N}, 7.00$. Found: C, 71.81; H, 5.02; N, 6.85 . ${ }^{1} \mathrm{H}$ NMR $\left(400 \mathrm{MHz}, \mathrm{CDCl}_{3}, \mathrm{ppm}\right) \delta=4.59\left(\mathrm{~s}, 4 \mathrm{H}, \mathrm{CH}_{2}-\mathrm{O}, \mathrm{CH}_{2}-\mathrm{O}\right), 7.19(\mathrm{~d}, J=8.8 \mathrm{~Hz}, 2 \mathrm{H}, \mathrm{Ar}-\mathrm{H})$, $7.25(\mathrm{~s}, 2 \mathrm{H}, \mathrm{Ar}-\mathrm{H}), 7.35(\mathrm{t}, J=3.6 \mathrm{~Hz}, 2 \mathrm{H}, \mathrm{Ar}-\mathrm{H}), 7.50(\mathrm{t}, J=4.2 \mathrm{~Hz}, 2 \mathrm{H}, \mathrm{Ar}-\mathrm{H}), 7.78(\mathrm{~d}, J=8.8 \mathrm{~Hz}, 2 \mathrm{H}$, Ar-H), $7.94(\mathrm{~d}, J=8.4 \mathrm{~Hz} 2 \mathrm{H}, \mathrm{Ar}-\mathrm{H}), 9.22(\mathrm{~s}, 2 \mathrm{H}, \mathrm{N}=\mathrm{CH}), 10.93(\mathrm{~s}, 2 \mathrm{H}, \mathrm{ArO}-\mathrm{H})$.

\subsection{Synthesis of Complex $\mathbf{1}$}

A pale-pink methanol solution $(2 \mathrm{~mL})$ of cobalt(II) picrate hexahydrate $(6.14 \mathrm{mg}, 0.01 \mathrm{mmol})$ was added dropwise to a colorless methanol solution $(2 \mathrm{~mL})$ of $\mathrm{H}_{2} \mathrm{~L}(4.00 \mathrm{mg}, 0.010 \mathrm{mmol})$ at room temperature. The mixing solution turned yellow immediately and the filtrate was allowed to stand at room temperature for about three weeks. Brown prismatic single crystals suitable for X-ray structural determination were obtained by slow evaporation from ethanol solution. (Yield: 39\% based on $\mathrm{Co}(\mathrm{Pic})_{2} \cdot 6 \mathrm{H}_{2} \mathrm{O}$ ). Anal. calcd. for $\mathrm{C}_{62} \mathrm{H}_{48} \mathrm{Co}_{3} \mathrm{~N}_{10} \mathrm{O}_{24}$ (\%): C, 49.85; H, 3.24; N, 9.38. Found: C, 49.97; $\mathrm{H}, 3.52 ; \mathrm{N}, 9.21$. 


\subsection{Synthesis of Complex 2}

Complex 2 was prepared by a similar procedure as complex 1 except for replacing cobalt(II) picrate hexahydrate with cobalt(II) acetate tetrahydrate. (Yield: $32 \%$ based on $\left.\mathrm{Co}(\mathrm{OAc})_{2} \cdot 4 \mathrm{H}_{2} \mathrm{O}\right)$. Anal. calcd. for $\mathrm{C}_{52} \mathrm{H}_{42} \mathrm{Co}_{3} \mathrm{~N}_{4} \mathrm{O}_{12}(\%)$ : C, 57.21; H, 3.88; N, 5.13. Found: $\mathrm{C}, 57.34 ; \mathrm{H}, 3.93 ; \mathrm{N}, 5.17$.

\subsection{Crystal Structure Determinations of Complexes $\mathbf{1}$ and $\mathbf{2}$}

The single crystals of complexes 1 and 2 with dimensions of $0.27 \times 0.25 \times 0.22 \mathrm{~mm}$ and $0.17 \times 0.09 \times 0.07 \mathrm{~mm}$ were placed on a Bruker Smart 1000 diffractometer equipped with an Apex $\mathrm{CCD}$ area detector. The diffraction data were collected using a graphite monochromatic $\mathrm{Cu} \mathrm{K \alpha}$ radiation $(\lambda=1.54178 \AA)$ and Mo $K \alpha$ radiation $(\lambda=0.71073 \AA)$, respectively. Empirical absorption correction was applied to the data using the SADABS program. The structure was solved by direct methods and refined by the full-matrix least squares method on $F^{2}$ using the SHELXL program. All non-hydrogen atoms were refined anisotropically. All the hydrogen atoms were generated geometrically and refined isotropically using the riding model. Details of the crystal parameters, data collection and refinements for complexes $\mathbf{1}$ and $\mathbf{2}$ are summarized in Table 1. The complete crystallographic data was deposited as a CIF file in the Cambridge Structural Database (CCDC Nos. 1522381 and 1522382 for complexes $\mathbf{1}$ and 2) and are available freely upon request citing the deposition number from the web site: www.ccdc.cam.ac.uk/data_request/cif.

Table 1. Crystal data and structure refinement for complexes $\mathbf{1}$ and $\mathbf{2 .}$

\begin{tabular}{|c|c|c|}
\hline Complex & 1 & 2 \\
\hline CCDC & 1522381 & 1522382 \\
\hline Molecular formula & $\mathrm{C}_{62} \mathrm{H}_{48} \mathrm{Co}_{3} \mathrm{~N}_{10} \mathrm{O}_{24}$ & $\mathrm{C}_{52} \mathrm{H}_{42} \mathrm{Co}_{3} \mathrm{~N}_{4} \mathrm{O}_{12}$ \\
\hline Molecular weight & 1493.89 & 1091.69 \\
\hline $\mathrm{T} / \mathrm{K}$ & $296(2)$ & 293(2) \\
\hline Wavelength $(\AA)$ & 1.54178 & 0.71073 \\
\hline Crystal system & Monoclinic & Triclinic \\
\hline Space group & $P 2(1) / n$ & $P-1$ \\
\hline$a / \AA$ & $15.0756(5)$ & $8.9123(7)$ \\
\hline$b / \AA$ & $10.7672(3)$ & $11.9798(9)$ \\
\hline$c / \AA$ & $18.6410(7)$ & $12.2170(7)$ \\
\hline$\alpha /\left(^{\circ}\right)$ & 90 & $111.581(6)$ \\
\hline$\beta /\left(^{\circ}\right)$ & $96.886(2)$ & $97.655(6)$ \\
\hline$\gamma /\left(^{\circ}\right)$ & 90 & $92.885(6)$ \\
\hline$V / \AA^{3}$ & 3004.02(17) & 1195.13(14) \\
\hline Z & 2 & 1 \\
\hline$D_{\mathrm{c}} /\left(\mathrm{gcm}^{-3}\right)$ & 1.652 & 1.517 \\
\hline$\mu /\left(\mathrm{mm}^{-1}\right)$ & 7.246 & 1.098 \\
\hline$F(000)$ & 1526 & 559 \\
\hline Crystal size $(\mathrm{mm})$ & $0.27 \times 0.25 \times 0.22$ & $0.17 \times 0.09 \times 0.07$ \\
\hline$\theta$ range for data collection $\left(^{\circ}\right)$ & 3.57 to 64.96 & 3.6740 to 28.4740 \\
\hline$h / k / l(\max , \min )$ & $-17,17 /-11,12 /-21,21$ & $-11,11 /-16,13 /-14,15$ \\
\hline Reflections collected & 18107 & 9426 \\
\hline Independent reflections & $5095 / 0.0569$ & $4687 / 0.0305$ \\
\hline Completeness to $\theta(\%)$ & 99.7 & 99.7 \\
\hline Data/restraints/parameters & $5095 / 0 / 389$ & $4687 / 0 / 323$ \\
\hline GOF on $F^{2}$ & 1.032 & 0.908 \\
\hline Final $R_{1}, w R_{2}[I>2 \sigma(I)]$ & $R_{1}=0.0593, w R_{2}=0.1043$ & $R_{1}=0.0446, w R_{2}=0.1326$ \\
\hline$R_{1}, w R_{2}$ indices (all data) & $R_{1}=0.0904, w R_{2}=0.1331$ & $R_{1}=0.0579, w R_{2}=0.1435$ \\
\hline Largest differences peak and hole $/ \mathrm{e}^{-3}$ & $-0.793,0.740$ & -0.334 and 0.410 \\
\hline
\end{tabular}




\section{Results and Discussion}

The complexes 1 and 2 were prepared by reaction of ligand $\mathrm{H}_{2} \mathrm{~L}$ with cobalt(II) picrate hexahydrate and cobalt(II) acetate tetrahydrate in ethanol, respectively. All compounds are stable in air. They are soluble in polar aprotic solvents such as DMF, DMSO, and $\mathrm{MeCN}$, slightly soluble in water, ethanol, ethylacetate, and chloroform, and insoluble in $\mathrm{Et}_{2} \mathrm{O}$ and petroleum ether. The elemental analyses show their different compositions.

\subsection{IR Spectra}

The IR spectra of $\mathrm{H}_{2} \mathrm{~L}$ and its corresponding complexes 1 and 2 exhibit various bands in the $400-4000 \mathrm{~cm}^{-1}$ region (Figure 1). The most important IR bands are listed in Table 2. In general, the $\mathrm{O}-\mathrm{H}$ stretching frequency of most compounds is usually expected in the $3300-3800 \mathrm{~cm}^{-1}$ region, but this frequency of the free ligand $\mathrm{H}_{2} \mathrm{~L}$ is displaced to $3437 \mathrm{~cm}^{-1}$ because of the intramolecular hydrogen bond $\mathrm{O}-\mathrm{H} \cdots \mathrm{N}=\mathrm{C}$ interaction. The free ligand exhibits characteristic $\mathrm{C}=\mathrm{N}$ stretching bands at $1631 \mathrm{~cm}^{-1}$, while those of complexes 1 and 2 were observed at 1603 and $1611 \mathrm{~cm}^{-1}$, respectively. The $\mathrm{C}=\mathrm{N}$ stretching frequencies are all shifted to lower frequencies by $28 \mathrm{~cm}^{-1}$ and $20 \mathrm{~cm}^{-1}$ upon complexation, indicating a decrease in the $\mathrm{C}=\mathrm{N}$ bond order due to the coordinated bond of the $\mathrm{Co}(\mathrm{II})$ atom with the imino nitrogen lone pair [50]. The Ar-O stretching frequency appears as a strong band at $1284 \mathrm{~cm}^{-1}$ for $\mathrm{H}_{2} \mathrm{~L}$ and at $1234 \mathrm{~cm}^{-1}$ for complex 2. Meanwhile, a bending vibration of phenolic alcohol in $\mathrm{H}_{2} \mathrm{~L}$ at $1182 \mathrm{~cm}^{-1}$, which disappears in the complexes, indicated the phenol hydroxy groups of $\mathrm{H}_{2} \mathrm{~L}$ were protonated and the oxygen atom coordinated to the $\mathrm{Co}(\mathrm{II})$ ions $[13,15]$. The Ar-O stretching frequency was shifted to a lower frequency, indicating that a $\mathrm{Co}-\mathrm{O}$ bond had been formed between the $\mathrm{Co}(\mathrm{II})$ ion and phenolic oxygen atom of the ligand.

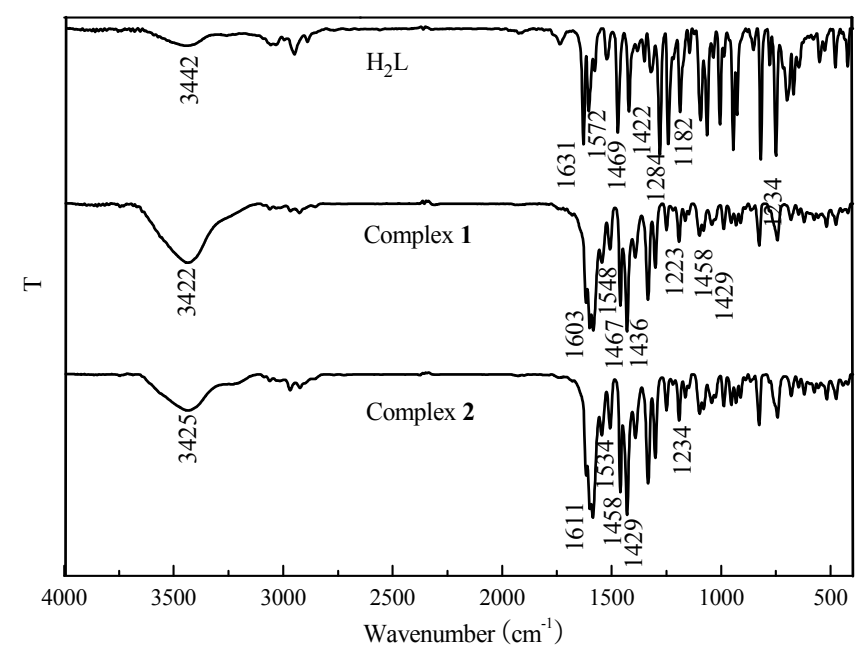

Figure 1. IR spectra of $\mathrm{H}_{2} \mathrm{~L}$ and the $\mathrm{Co}(\mathrm{II})$ complexes $\mathbf{1}$ and 2.

Table 2. The most important IR bands of the ligand $\mathrm{H}_{2} \mathrm{~L}$ and complexes $\mathbf{1}$ and $\mathbf{2}\left(\mathrm{cm}^{-1}\right)$.

\begin{tabular}{|c|c|c|c|c|c|c|c|c|}
\hline Compound & $v_{(\mathrm{O}-\mathrm{H})}$ & $v_{(\mathrm{C}=\mathrm{N})}$ & $v_{(\mathrm{Ar}-\mathrm{O})}$ & $v_{(\mathrm{Co}-\mathrm{N})}$ & $v_{(\mathrm{Co}-\mathrm{O})}$ & $v_{(\mathrm{C}=\mathrm{C})}$ & Benzene $\mathbf{R} \mathbf{i}$ & eleton \\
\hline $\mathrm{H}_{2} \mathrm{~L}$ & 3442 & 1631 & 1284 & - & - & 1572 & 1472 & 1422 \\
\hline Complex 1 & 3422 & 1603 & 1223 & 452 & 431 & 1548 & 1467 & 1436 \\
\hline Complex 2 & 3425 & 1611 & 1234 & 446 & 422 & 1534 & 1458 & 1429 \\
\hline
\end{tabular}

The far-infrared spectra of complexes 1 and 2 were also obtained in the region $500-100 \mathrm{~cm}^{-1}$ in order to identify frequencies due to the $\mathrm{Co}-\mathrm{O}$ and $\mathrm{Co}-\mathrm{N}$ bonds. The FT-IR spectra of the complexes 1 and 2 showed $v(\mathrm{Co}-\mathrm{N})$ and $v(\mathrm{Co}-\mathrm{O})$ vibration absorption frequencies possibly at $452,446 \mathrm{~cm}^{-1}$ and 
431, $422 \mathrm{~cm}^{-1}$, respectively. But as pointed out by Percy and Thornton [51], the metal-oxygen and metal-nitrogen frequency assignments are at times very difficult.

\subsection{UV-Vis Spectra}

The UV-Vis absorption spectra of $\mathrm{H}_{2} \mathrm{~L}$ and its corresponding complexes $\mathbf{1}$ and 2 in $5.0 \times 10^{-5} \mathrm{~mol} \cdot \mathrm{L}^{-1} \mathrm{DMF}$ solution are shown in Figure 2. The electronic absorption spectrum of the free ligand $\mathrm{H}_{2} \mathrm{~L}$ consists of two relatively intense bands at $230 \mathrm{~nm}, 316 \mathrm{~nm}$ and one weak band at $357 \mathrm{~nm}$, the first absorptions observed at $230 \mathrm{~nm}$ and $316 \mathrm{~nm}$ can be signed to the $\pi-\pi^{*}$ transition of the benzene rings, while the absorption peak at $357 \mathrm{~nm}$ was attributed to the intra-ligand $\pi-\pi^{*}$ transition of the oxime group [52]. The complexes $\mathbf{1}$ and $\mathbf{2}$ show almost identical UV-Vis absorption spectra. The absorption bands around $313 \mathrm{~nm}$ are only marginally red-shifted $(4-6 \mathrm{~nm})$ in the spectra of the complexes. Upon coordination of the ligands, the absorption bands at about $357 \mathrm{~nm}$ disappeared and the new bands at $256 \mathrm{~nm}$ appeared in the UV-Vis spectra of the complexes $\mathbf{1}$ and 2, which indicates that the oxime nitrogen atoms are involved in coordination to $\mathrm{Co}(\mathrm{II})$ atoms [53]. In addition, the other new absorption peak is observed at ca. $391 \mathrm{~nm}$ in Co(II) complexes, which is attributed to the $\mathrm{M} \rightarrow \mathrm{L}$ charge-transfer transition. This is characteristic of the transition metal complexes with Salen-type ligands [54,55].

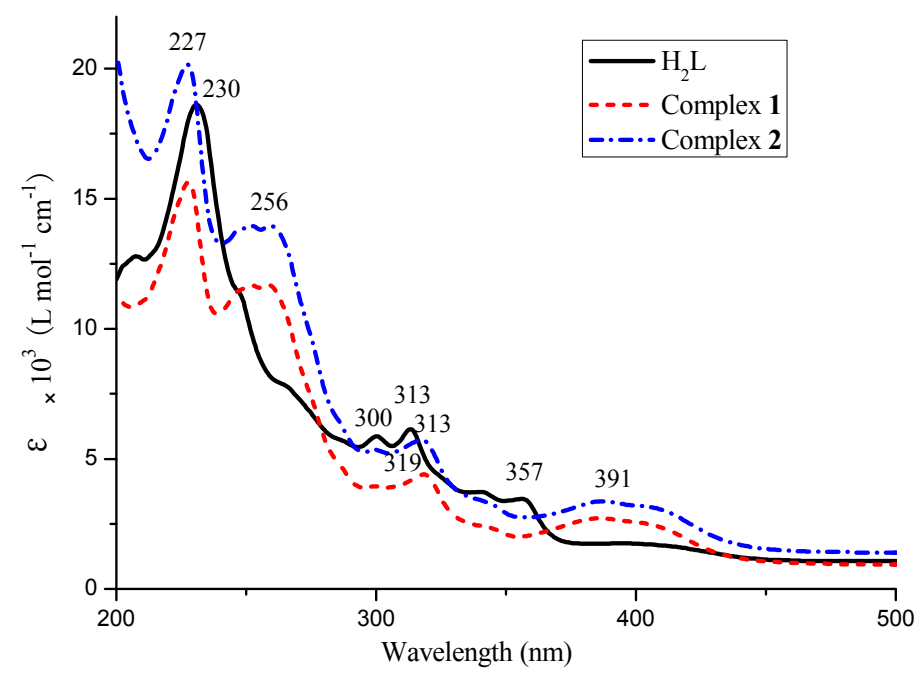

Figure 2. UV-Vis absorption spectra of $\mathrm{H}_{2} \mathrm{~L}$ and the $\mathrm{Co}(\mathrm{II})$ complexes $\mathbf{1}$ and $\mathbf{2}$ in dilute DMF solution at room temperature $\left(\mathrm{c}=5 \times 10^{-5} \mathrm{~mol} / \mathrm{L}\right)$.

\subsection{Crystal Structure of Complexes $\mathbf{1}$ and $\mathbf{2}$}

The crystal structures of complexes $\mathbf{1}$ and $\mathbf{2}$ with an atom numbering scheme is exhibited in Figures 3 and 4 . The selected bond lengths and angles of complexes 1 and 2 are in Table 3 . The complex 1 crystallizes in the monoclinic system and $P 2(1) / n$ space group and $Z=1$. The complex 1 consist of two $[\mathrm{CoL}]$ and one $\left[\mathrm{Co}(\mathrm{Pic})_{2}\left(\mathrm{CH}_{3} \mathrm{OH}\right)_{2}\right]$ molecules, and in [CoL] molecule, the $\mathrm{Co} 1$ atom is tetra-coordinated by two phenoxy $\mathrm{O}$ and two oxime $\mathrm{N}$ atoms from one ligand anion $\mathrm{L}^{2-}$. The $\mathrm{O} 1, \mathrm{O} 2, \mathrm{~N} 1, \mathrm{~N} 2$ atoms from the same ligand anion consist of the square plane with the dihedral angle of N1-N2-O1and O1-O2-N1 of $2.30^{\circ}$, and the $\mathrm{Co}(\mathrm{II})$ atom deviates from the plane $0.069 \AA$. The $\mathrm{Co}-\mathrm{O} / \mathrm{N}$ bond distances in the square plane are in the range of 1.917(2) to 2.013(2) $\AA$. Therefore, the local coordination geometry around the Co1 center can be described as a distorted square-planar as shown in Figure $3 \mathrm{~b}$. 

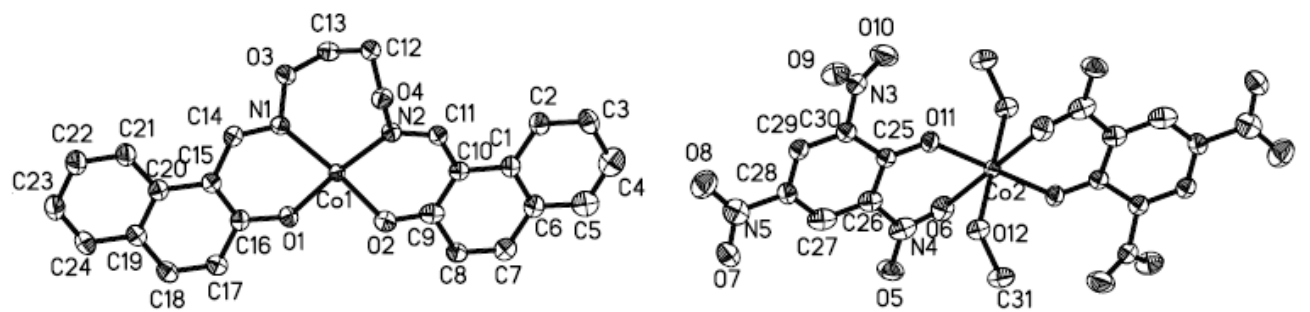

(a)
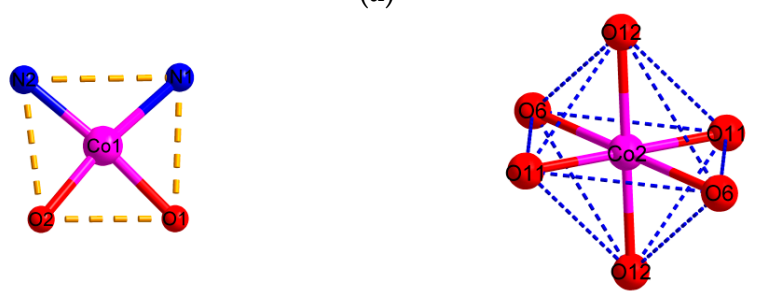

(b)

Figure 3. (a) View of the coordination environment of $\mathrm{Co}(\mathrm{II})$ center with thermal ellipsoids at $30 \%$ probability in $\mathbf{1}$ with a labelling scheme (all $\mathrm{H}$ atoms have been omitted for clarity); (b) The coordination polyhedron of $\mathrm{Co}(\mathrm{II})$ in $\mathbf{1}$.

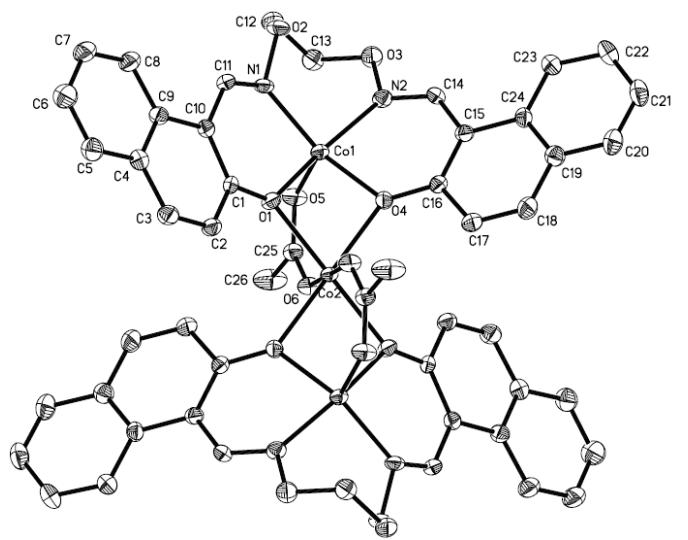

(a)

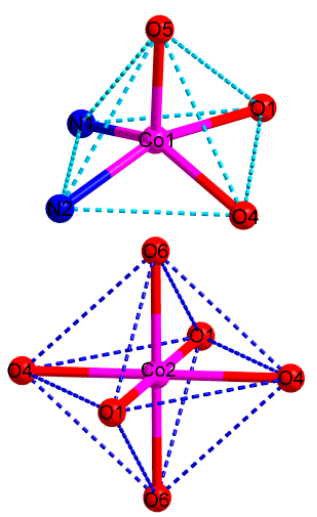

(b)

Figure 4. (a) View of the coordination environment of Co(II) center with thermal ellipsoids at $30 \%$ probability in $\mathbf{2}$ with a labelling scheme (all $\mathrm{H}$ atoms have been omitted for clarity); (b) The coordination polyhedron of $\mathrm{Co}(\mathrm{II})$ in 2.

The $\left[\mathrm{Co}(\mathrm{Pic})_{2}\left(\mathrm{CH}_{3} \mathrm{OH}\right)_{2}\right]$ molecule is rigorously centrosymmetric, and contains one $\mathrm{Co}(\mathrm{II})$ center, two $\mathrm{Pic}^{-}$and two coordinated methanol molecules. The $\mathrm{Co}(\mathrm{II})$ atom is hexa-coordinated by two phenoxy $\mathrm{O}$ and two nitro $\mathrm{O}$ atoms from two $\mathrm{Pic}^{-}$, and the other two $\mathrm{O}$ atoms from two coordinated methanol molecules to form an octahedral geometry as shown in Figure $3 \mathrm{~b}$. The O6, O11, ${ }^{\mathrm{i}}{ }^{\mathrm{i}}$, and $\mathrm{O} 11^{\mathrm{i}}$ atoms constitute the equatorial plane with the dihedral angle of $\mathrm{O} 6-\mathrm{O} 6^{\mathrm{i}}-\mathrm{O} 11$ and $\mathrm{O} 11-\mathrm{O} 11^{\mathrm{i}}-\mathrm{O} 6$ of $0.00^{\circ}$, and the $\mathrm{Co}(\mathrm{II})$ atom strays from the plane $0.00 \AA$. The $\mathrm{Co}-\mathrm{O} / \mathrm{N}$ bond distances in the equatorial plane are in the range of 1.904(2) to 2.335(2) $\AA$. The axial positions are occupied by $\mathrm{O} 12$ and $\mathrm{O} 12^{\mathrm{i}}$ from methanol molecules with bond lengths of $1.993 \AA$. The trans-coordination angles of $\mathrm{O} 12-\mathrm{Co} 2-\mathrm{O} 12^{\mathrm{i}}, \mathrm{O}^{\mathrm{i}}-\mathrm{Co} 2-\mathrm{O} 6$,

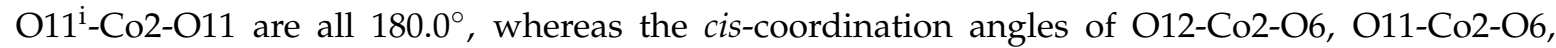
O12-Co2-O11 are $82.92(6)^{\circ}, 81.33(7)^{\circ}, 89.82(7)^{\circ}$, respectively. Therefore, the local coordination geometry around the $\mathrm{Co} 2$ center can be described as a slightly distorted octahedron.

According to the above, this complex is very interesting from the structural point of view. First, complex 1 with the picrate anion contains in the crystal structurethe tetracoordinate molecule $[\mathrm{Co}(\mathrm{L})]$ with a distorted square planar coordination geometry. This geometry is rather rare for the 
Co(II) complexes, especially when the abundance of this topology is compared with the tetrahedral and distorted tetrahedral geometries. Second, in the CSD only five other examples of Co(II) complexes with coordinated picrate anions can be found. Two of them, the nitro oxygen atoms of the picrate anion were not involved in coordination with $\mathrm{Co}$ (II) ions and in the other three $\mathrm{Co}$ (II) complexes [56-58], the coordination mode of picric anions is consistent with the coordination pattern reported in this paper. The Co-O $\left(\mathrm{NO}_{2}\right)$ bond lengths in complex $\mathbf{1}$ is $2.335 \AA$, which is within the range of previously published Co(II) complexes involving coordinated picrate anion with that of $2.459 \AA$, $2.190 \AA, 2.110 \AA$, and $2.149 \AA$ [57-59], respectively.

Table 3. Selected bond distances $(\AA)$ and angles $\left(^{\circ}\right)$ for complexes $\mathbf{1}$ and $\mathbf{2}$.

\begin{tabular}{|c|c|c|c|c|c|}
\hline \multicolumn{6}{|c|}{1} \\
\hline Co1-O1 & $1.917(2)$ & Co1-O2 & $1.936(2)$ & Co1-N1 & $2.013(2)$ \\
\hline Co1-N2 & $1.933(2)$ & Co2-O11 & $1.904(2)$ & Co2-O12 & $1.993(2)$ \\
\hline $\mathrm{Co} 2-\mathrm{O} 6$ & $2.335(2)$ & $\mathrm{Co} 2-\mathrm{O} 11^{\mathrm{i}}$ & $1.904(2)$ & $\mathrm{Co} 2-\mathrm{O} 12^{\mathrm{i}}$ & $1.993(2)$ \\
\hline $\mathrm{Co} 2-\mathrm{O}^{\mathrm{i}}$ & $2.335(2)$ & & & & \\
\hline O1-Co1-N2 & $172.74(7)$ & O1-Co1-O2 & $85.48(7)$ & N2-Co1-O2 & $87.76(7)$ \\
\hline O1-Co1-N1 & $86.78(7)$ & N2-Co1-N1 & $99.72(8)$ & O2-Co1-N1 & $170.84(8)$ \\
\hline $\mathrm{O} 11^{\mathrm{i}-\mathrm{Co} 2-\mathrm{O} 11}$ & 180.0 & 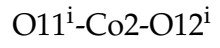 & $89.82(7)$ & O11-Co2-O12 ${ }^{\mathrm{i}}$ & $90.18(7)$ \\
\hline $\mathrm{O} 11^{\mathrm{i}-\mathrm{Co} 2-\mathrm{O} 12}$ & $90.18(7)$ & O11-Co2-O12 & $89.82(7)$ & 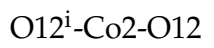 & 180.0 \\
\hline $\mathrm{O} 11^{\mathrm{i}}-\mathrm{Co} 2-\mathrm{O} 6^{\mathrm{i}}$ & 81.33(7) & O11-Co2-O6 ${ }^{\mathrm{i}}$ & $98.67(7)$ & 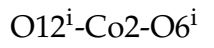 & $82.92(6)$ \\
\hline $\mathrm{O} 12-\mathrm{Co} 2-\mathrm{O}^{\mathrm{i}}$ & $97.08(6)$ & $\mathrm{O} 11^{\mathrm{i}-\mathrm{Co} 2-\mathrm{O} 6}$ & $98.67(7)$ & O11-Co2-O6 & 81.33(7) \\
\hline $\mathrm{O} 12^{\mathrm{i}}-\mathrm{Co} 2-\mathrm{O} 6$ & $97.08(6)$ & O12-Co2-O6 & $82.92(6)$ & $\mathrm{O}^{\mathrm{i}}-\mathrm{Co} 2-\mathrm{O} 6$ & 180.0 \\
\hline \multicolumn{6}{|c|}{2} \\
\hline Co2-O6 & $2.037(2)$ & $\mathrm{Co} 2-\mathrm{O} 4$ & $2.170(2)$ & $\mathrm{Co} 2-\mathrm{O} 1$ & $2.143(2)$ \\
\hline $\mathrm{Co} 2-\mathrm{O}^{\mathrm{i}}$ & $2.037(2)$ & $\mathrm{Co} 2-\mathrm{O} 4^{\mathrm{i}}$ & $2.170(2)$ & $\mathrm{Co} 2-\mathrm{O} 1^{\mathrm{i}}$ & $2.143(2)$ \\
\hline Co1-O4 & $1.977(2)$ & Co1-O5 & $1.980(2)$ & Co1-O1 & $2.060(2)$ \\
\hline Co1-N1 & $2.020(3)$ & Co1-N2 & $2.045(3)$ & & \\
\hline O4-Co1-O5 & 103.11(1) & O4-Co1-O1 & $82.05(8)$ & O4-Co1-N1 & $144.54(1)$ \\
\hline O4-Co1-N2 & $87.49(9)$ & O5-Co1-O1 & $94.72(10)$ & O5-Co1-N1 & 111.18(1) \\
\hline O5-Co1-N2 & 101.21(1) & N1-Co1-O1 & $86.34(9)$ & N1-Co1-N2 & $94.33(1)$ \\
\hline N2-Co1-O1 & $162.59(1)$ & O6-Co2-O4 & $90.42(9)$ & O6-Co2-O1 & $89.82(9)$ \\
\hline O6-Co2-O6 ${ }^{\mathrm{i}}$ & 180.0 & $\mathrm{O} 6-\mathrm{Co} 2-\mathrm{O} 4^{\mathrm{i}}$ & $89.58(9)$ & $\mathrm{O} 6-\mathrm{Co} 2-\mathrm{O} 1^{\mathrm{i}}$ & $90.18(9)$ \\
\hline O6-Co2-O1 & $90.18(9)$ & $\mathrm{O} 6^{\mathrm{i}}-\mathrm{Co} 2-\mathrm{O} 4$ & $89.58(9)$ & 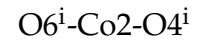 & $90.42(9)$ \\
\hline $\mathrm{O} 6^{\mathrm{i}}-\mathrm{Co} 2-\mathrm{O} 1^{\mathrm{i}}$ & $89.82(9)$ & $\mathrm{O} 4^{\mathrm{i}-\mathrm{C}} 2-\mathrm{O} 4$ & 180.0 & $\mathrm{O} 1-\mathrm{Co} 2-\mathrm{O} 4^{\mathrm{i}}$ & 104.19(8) \\
\hline 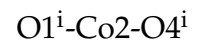 & $75.81(8)$ & $\mathrm{O} 1-\mathrm{Co} 2-\mathrm{O} 4$ & 75.82(8) & $\mathrm{O} 1^{\mathrm{i}-\mathrm{Co} 2-\mathrm{O} 4}$ & $104.19(8)$ \\
\hline O1-Co2-O1 & 180.0 & & & & \\
\hline
\end{tabular}

The complex 2 crystallizes in the triclinic system and $P-1$ space group, $Z=2$. The symmetric $\left[\{\mathrm{CoL}(\mu-\mathrm{OAc})\}_{2} \mathrm{Co}\right]$ unit consists of three $\mathrm{Co}(\mathrm{II})$ atoms, two ligand anion $\mathrm{L}^{2-}$ units, and two coordinated acetate ions. The terminal $\mathrm{Co}$ (II) atom $\left(\mathrm{Co} 1\right.$ and $\left.\mathrm{Co}^{\mathrm{i}}\right)$ is penta-coordinated by two nitrogen atoms (N1 and N2), two oxygen atoms (O1 and $\mathrm{O} 4)$ in the $\mathrm{N}_{2} \mathrm{O}_{2}$ moiety of the $\mathrm{L}^{2-}$ unit, and one oxygen atom (O5) from the bridging acetate anion. Crystallographic data $\tau=0.13$ suggests a slightly distorted tetragonal pyramid coordination arrangement for the complex 2 [59]. However, the coordination geometry of the hexa-coordinated central $\mathrm{Co} 2$ atom deviates slightly from an ideal octahedron. The $\mathrm{Co} 2$ atom has an $\mathrm{O}_{2} \mathrm{O}_{2}$ donor set from four $\mu$-phenoxo oxygen atoms $\left(\mathrm{O} 1, \mathrm{O} 4, \mathrm{O}^{\mathrm{i}}, \mathrm{O}^{\mathrm{i}}\right)$ from two [CoL] chelates. Meanwhile, each of the two acetate anions bridges the terminal Co1 and central Co2 atoms in a syn-syn fashion. Hence the central $\mathrm{Co} 2$ atom finally has an $\mathrm{O}_{2} \mathrm{O}_{2} \mathrm{O}_{2}$ donor set, in which the coordination sphere is completed by $\mu$-phenoxo oxygen atoms $\left(\mathrm{O} 1, \mathrm{O} 4, \mathrm{O} 1^{\mathrm{i}}, \mathrm{O} 4^{\mathrm{i}}\right)$ from two $[\mathrm{CoL}]$ chelates, and both of oxygen atoms $\mathrm{O} 6$ and ${ }^{2} 6^{i}$ from the ligating acetate ions which adopt a familiar $\mu$-O-C-O fashion, and constitute a slightly distorted octahedral geometry. The $\mathrm{Co} 2-\mathrm{O}$ bond distances are in the range of 2.037(2) to 2.170(2) $\AA$, the coordinated angles of O1-Co2-O1 $1^{\mathrm{i}}, \mathrm{O} 4-\mathrm{Co} 2-\mathrm{O} 4^{\mathrm{i}}$, and O6-Co2-O6 ${ }^{\mathrm{i}}$ are all $180^{\circ}$. Therefore, the local coordination geometry around the central $\mathrm{Co} 2$ atom can be described as deviating 
slightly from the ideal octahedron as shown in Figure $4 \mathrm{~b}$. The trinuclear structure is stabilized by the two $\mu$-acetato ligands bridging Co2-Co1 and Co2-Co1 ${ }^{i}$ with shorter separations of $\mathrm{Co} \cdots \mathrm{Co}(3.065 \AA)$, which neutralize the whole charge of complex 2.

\subsection{Supramolecular Interaction of Complexes $\mathbf{1}$ and $\mathbf{2}$}

It should be noted that important intermolecular hydrogen bonding interactions exist between the molecules in complex $\mathbf{1}$ as listed in Table 4 . Firstly, intermolecular hydrogen bonds between the coordinated methanol molecules of $\left[\mathrm{Co}(\mathrm{Pic})_{2}\left(\mathrm{CH}_{3} \mathrm{OH}\right)_{2}\right]$ unit and oxygen atoms of the $\mu$-naphthoxo group in the ligand anion $\mathrm{L}^{2-}$ of $[\mathrm{CoL}]$ unit, $\mathrm{O} 12-\mathrm{H} 12 \mathrm{C} \cdots \mathrm{O} 1$, are formed between the $[\mathrm{CoL}]$ and $\left[\mathrm{Co}(\mathrm{Pic})_{2}\left(\mathrm{CH}_{3} \mathrm{OH}\right)_{2}\right]$ units which link the neighboring one $\left[\mathrm{Co}(\mathrm{Pic})_{2}\left(\mathrm{CH}_{3} \mathrm{OH}\right)_{2}\right]$ unit and two [CoL] units into a tri-polymer as shown in Figure 5. In addition, every tri-polymer further links eight other adjacent tri-polymer units into an infinite 3D-network supramolecular structure by four pairs of

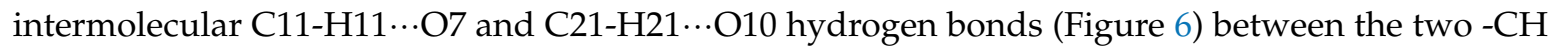
groups of the ligand anion $\mathrm{L}^{2-}$ in $[\mathrm{CoL}]$ units and the oxygen atoms of the picric acid anion $\mathrm{Pic}^{-}$in $\left[\mathrm{Co}(\mathrm{Pic})_{2}\left(\mathrm{CH}_{3} \mathrm{OH}\right)_{2}\right]$ units, respectively. Furthermore, this linkage is further stabilized by the $\pi \cdots \pi$ stacking between the benzene ring (Table 5 and Figure 7 ) of the adjacent $[\mathrm{CoL}]$ and $\left[\mathrm{Co}(\mathrm{Pic})_{2}\left(\mathrm{CH}_{3} \mathrm{OH}\right)_{2}\right]$ units. Consequently, with the help of $\mathrm{O}-\mathrm{H} \cdots \mathrm{O}$ and $\mathrm{C}-\mathrm{H} \cdots \mathrm{O}$ hydrogen bonds, $\pi \cdots \pi$ stacking interactions, the crystal structure of $\mathbf{1}$ shows an assembly 3D supramolecular network structure (Figure 8) introduced by a coordinated picrate.

Table 4. The main hydrogen bonds $\left[\AA^{\circ},{ }^{\circ}\right]$ for complex $\mathbf{1}$.

\begin{tabular}{lccccc}
\hline \multicolumn{1}{c}{$\mathbf{D}-\mathbf{H} \cdots \mathbf{A}$} & $\mathbf{d}(\mathbf{D}-\mathbf{H})$ & $\mathbf{d}(\mathbf{H} \cdots \mathbf{A})$ & $\mathbf{d}(\mathbf{D} \cdots \mathbf{A})$ & $\angle \mathbf{D}-\mathbf{H} \cdots \mathbf{A}$ & Symmetry Code \\
\hline $\mathrm{O} 12-\mathrm{H} 12 \mathrm{C} \cdots \mathrm{O} 1$ & 0.85 & 1.78 & $2.554(2)$ & 150 & $\mathrm{x}, \mathrm{y},-1+\mathrm{z}$ \\
$\mathrm{C} 11-\mathrm{H} 11 \cdots \mathrm{O} 7$ & 0.93 & 2.48 & $3.383(4)$ & 165 & $1 / 2+\mathrm{x}, 1 / 2-\mathrm{y}, 1 / 2+\mathrm{z}$ \\
$\mathrm{C} 21-\mathrm{H} 21 \cdots \mathrm{O} 10$ & 0.93 & 2.57 & $3.463(2)$ & 161 & $3 / 2-\mathrm{x},-1 / 2+\mathrm{y}, 3 / 2-\mathrm{z}$ \\
\hline
\end{tabular}

Table 5. Putative $\pi-\pi$ stacking interactions [̊̊] for complex $\mathbf{1}$.

\begin{tabular}{cccccc}
\hline Ring $(\mathbf{I})$ & Ring $(\mathbf{J})$ & $d(\mathbf{C g}-\mathbf{C g})$ & $d(\mathbf{C g}(\mathbf{I})$-perp) & $d(\mathbf{C g}(\mathbf{J})$-perp) & Slippage \\
\hline Cg5 & Cg1 & $3.6242(13)$ & $3.4264(9)$ & $3.5081(9)$ & 0.910 \\
Cg1 & Cg6 & $3.6684(13)$ & $-3.5593(9)$ & $3.6439(9)$ & 0.4232 \\
Cg6 & Cg4 & $3.6866(14)$ & $-3.3947(9)$ & $3.5010(11)$ & 1.155 \\
Cg4 & Cg7 & $3.7938(16)$ & $-3.4919(11)$ & $-3.6100(12)$ & 1.167 \\
Cg5 & Cg6 & $3.6941(13)$ & $-3.2919(9)$ & $-3.3612(9)$ & 1.533 \\
\hline
\end{tabular}

$\mathrm{Cg} 1, \mathrm{Cg} 4, \mathrm{Cg} 5, \mathrm{Cg} 6$, and $\mathrm{Cg} 7$ are the centroids of benzene ring C25-C30, C1-C6, C1-C6-C10, C15-C20, and C19-C24 of complex $\mathbf{1}$, respectively.

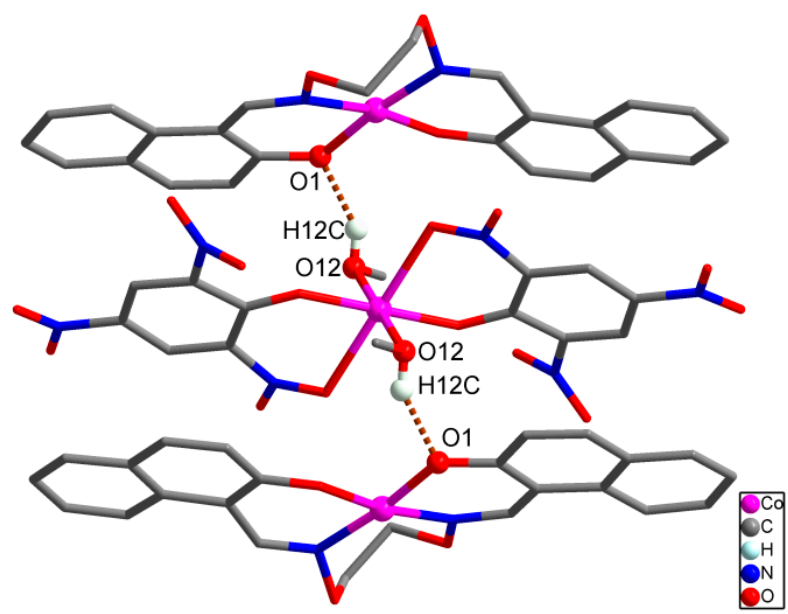

Figure 5. The tri-polymer constructed by intermolecular $\mathrm{O}-\mathrm{H} \cdots \mathrm{O}$ hydrogen bonds in $\mathbf{1}$. 


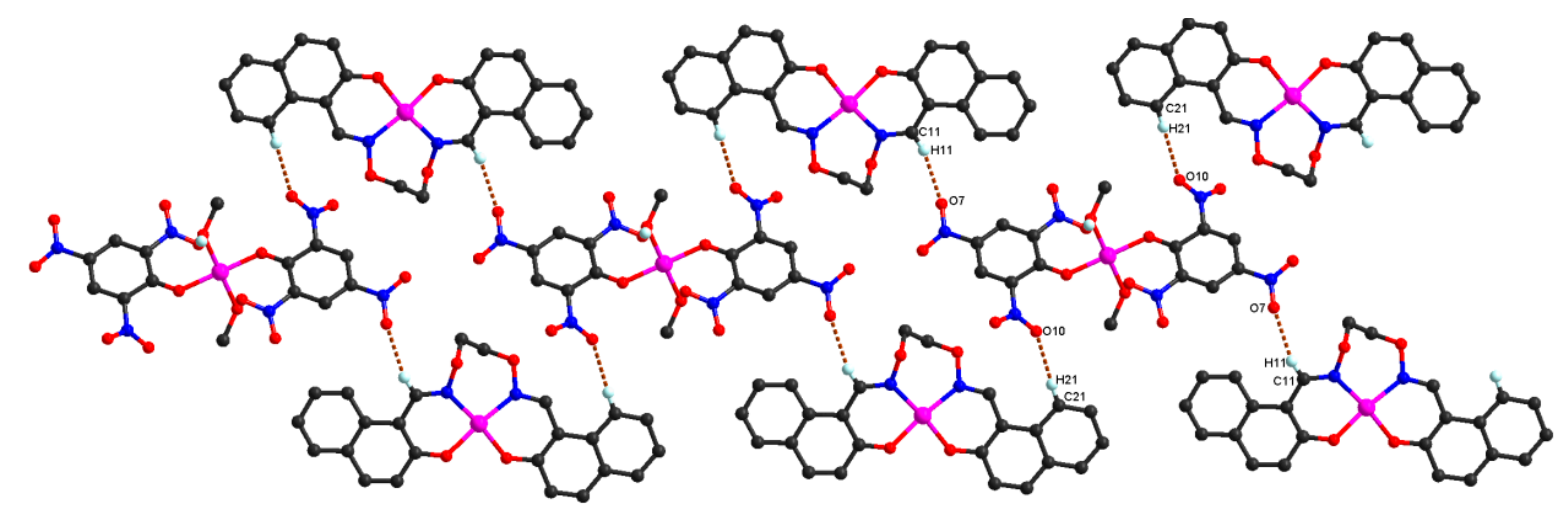

Figure 6. Part of intermolecular $\mathrm{C}-\mathrm{H} \cdots \mathrm{O}$ hydrogen-bonding interactions in $\mathbf{1}$.

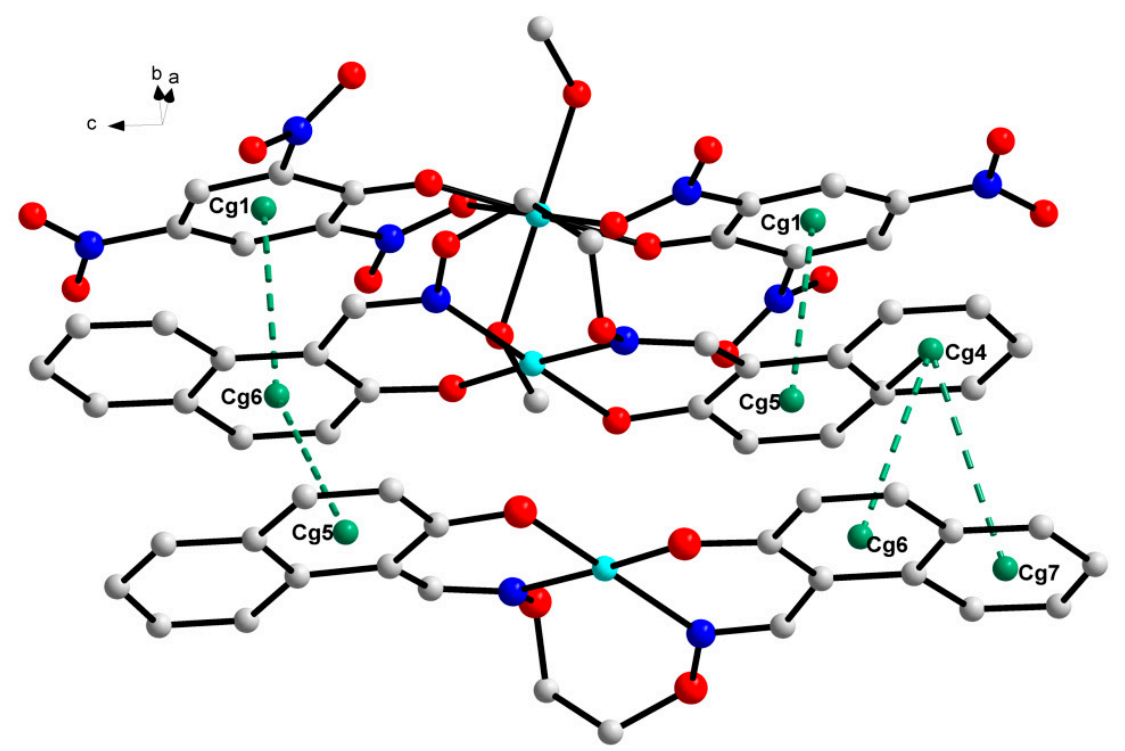

Figure 7. View of supramolecular structure of complex 1 showing the formation five $\pi \cdots \pi$ stacking interaction.

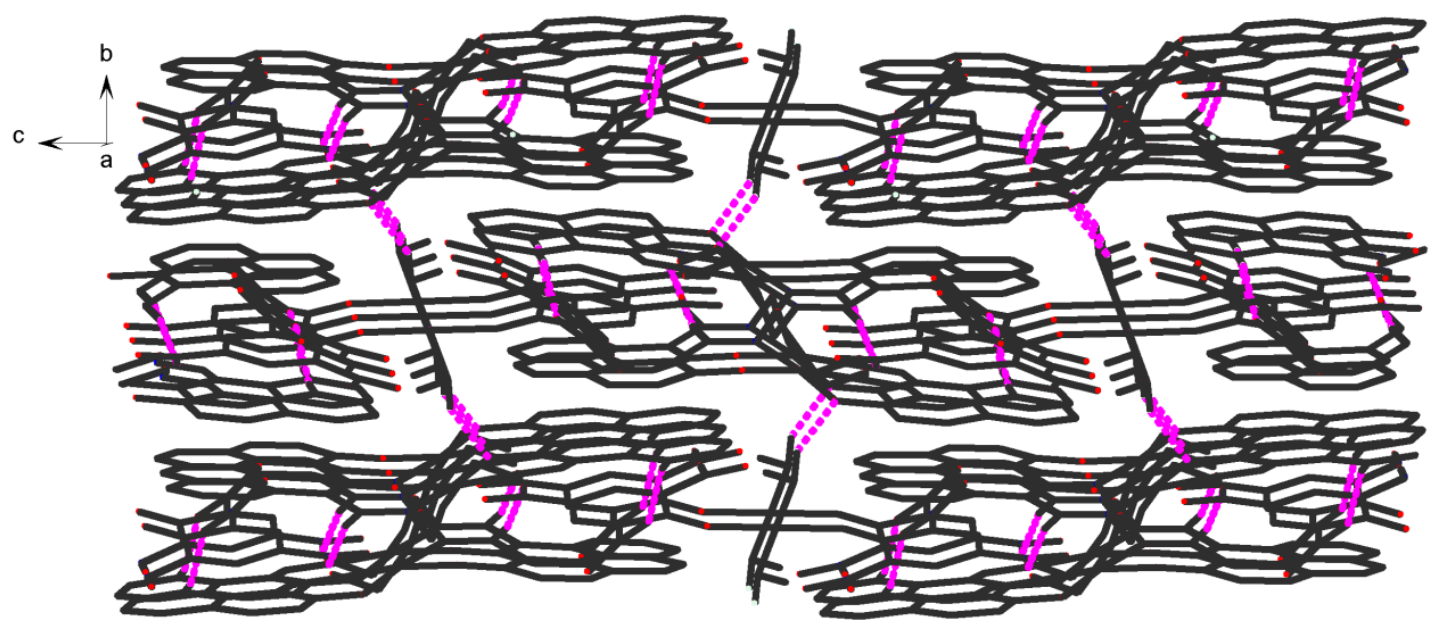

Figure 8. Part of 3D supramolecular network structure in $\mathbf{1 .}$

In the crystal structure of 2, a pair of intramolecular C13-H13A $\cdots$ O5 hydrogen bonds are formed between the oxygen (O5) atom of the coordinated acetate anion and the $-\mathrm{C} 13 \mathrm{H} 13 \mathrm{~A}$ group of the 
O-alkyl chain of $\mathrm{L}^{2-}$ unit as shown in Figure 9. The hydrogen bond data are given in Table 6. Complex 2 is stabilized by intermolecular $\mathrm{C} 6-\mathrm{H} 6 \cdots \pi_{\text {centroid(C19-C24) }}$ interactions between the - $\mathrm{CH}$ group of the benzene ring and the aromatic rings of $\mathrm{L}^{2-}$ unit linking the neighboring molecules into a 1D infinite chain parallel to the $c$ axis (Figure 10). Synchronously, this linkage is further stabilized by a pair of intermolecular $\pi_{\text {centroid(C15-C19,C24) }}{ }^{-} \pi_{\text {centroid(C19-C24) }}$ stacking interactions between the aromatic rings to form the other 1D infinite chain along $b$ axis (Figure 11 and Table 7). Then these two 1D chains interlink with each other resulting in the crystal packing of $\mathbf{2}$ showing a 2D-layer supramolecular structure parallel to the $b c$-planes (Figure 12).

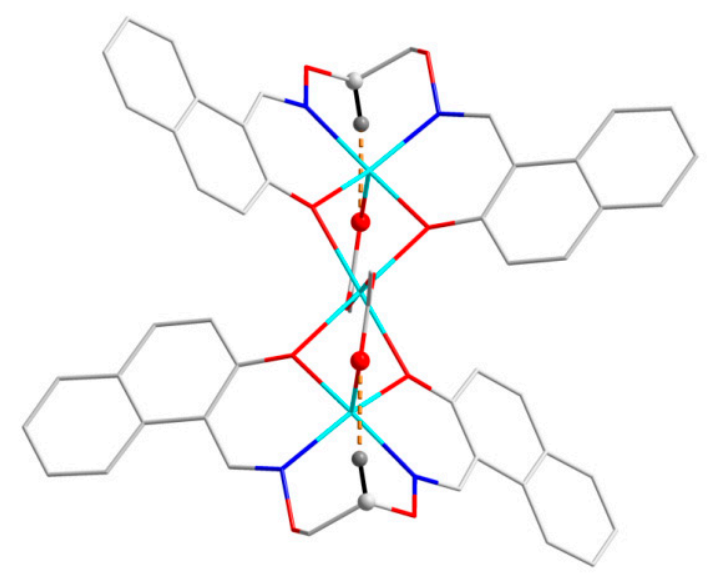

Figure 9. Intramolecular hydrogen bonds in complex 2 (hydrogen atoms, except those forming hydrogen bonds, are omitted for clarity).

Table 6. The main hydrogen bonds $\left[\AA^{\circ},{ }^{\circ}\right]$ for complex 2 .

\begin{tabular}{cccccc}
\hline D-H $\cdots \mathbf{A}$ & $\mathbf{d}(\mathbf{D}-\mathbf{H})$ & $\mathbf{d}(\mathbf{H} \cdots \mathbf{A})$ & $\mathbf{d}(\mathbf{D} \cdots \mathbf{A})$ & $\angle \mathrm{D}-\mathrm{H} \cdots \mathbf{A}$ & Symmetry Operation \\
\hline $\mathrm{C} 13-\mathrm{H} 13 \mathrm{~A} \cdots \mathrm{O} 5$ & 0.97 & 2.31 & $3.233(4)$ & 160 & $\mathrm{x}, \mathrm{y}, \mathrm{z}$ \\
$\mathrm{C} 6-\mathrm{H} 6 \cdots \mathrm{Cg} 2$ & 3.753 & 3.119 & $2.93(2)$ & 167 & $1+\mathrm{x}, \mathrm{y}, 1+\mathrm{z}$ \\
\hline
\end{tabular}

$\mathrm{Cg} 2$ is the centroid of benzene ring C19-C24 of complex 2.

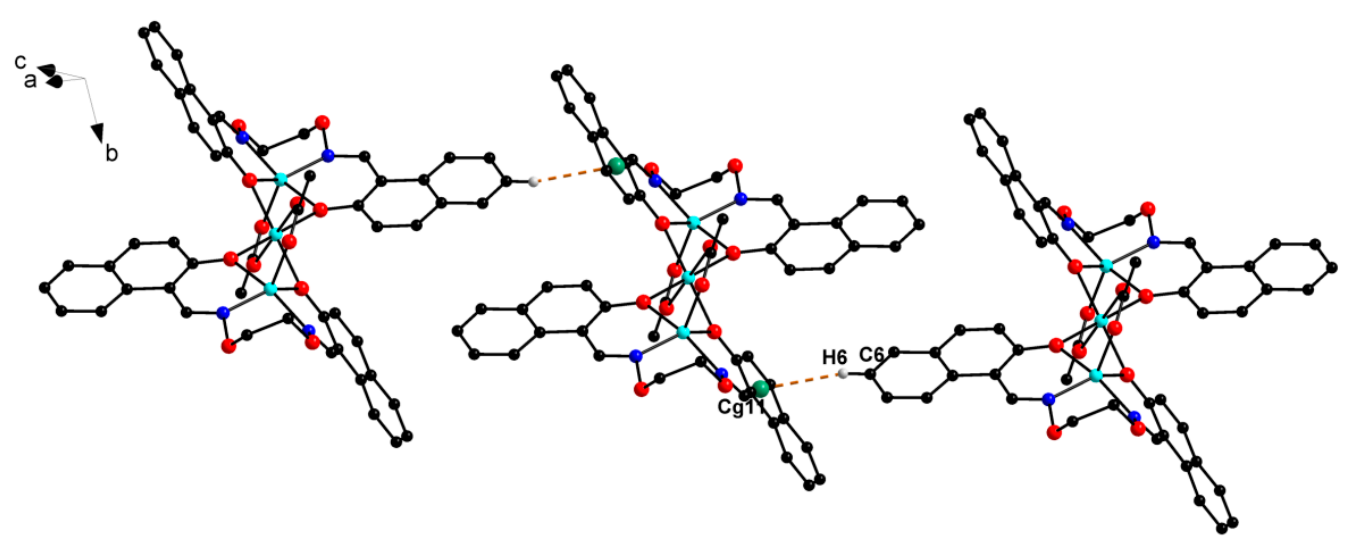

Figure 10. View of $1 \mathrm{D}$ supramolecular structure of the complex 2 showing the formation C-H $\cdots \pi$ stacking interaction. 


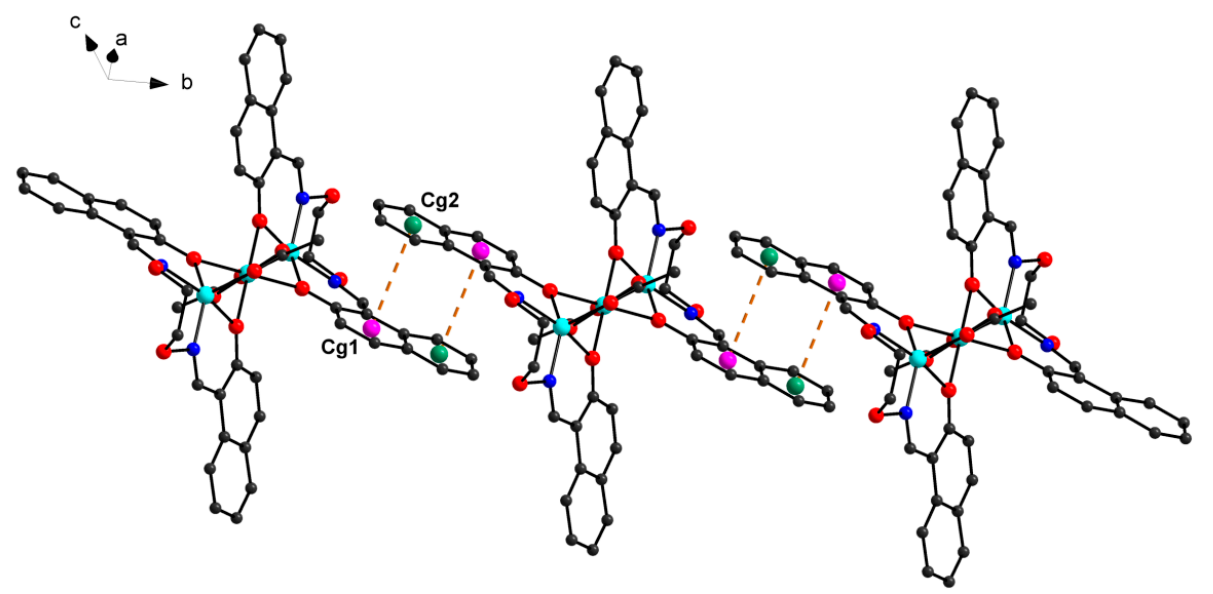

Figure 11. View of 1D supramolecular structure of the complex 2 showing the formation $\pi \cdots \pi$ stacking interaction.

Table 7. Putative $\pi-\pi$ stacking interactions [̊] for complex 2 .

\begin{tabular}{cccccc}
\hline Ring (I) & Ring (J) & Cg-Cg & Cg(I)-perp & Cg(J)-perp & Slippage \\
\hline Cg1 & Cg2 & $3.703(2)$ & $3.4883(14)$ & $3.5153(16)$ & 1.163 \\
\hline
\end{tabular}

$\mathrm{Cg} 1$ and $\mathrm{Cg} 2$ are the centroids of benzene ring $\mathrm{C} 15-\mathrm{C} 19, \mathrm{C} 24$, and $\mathrm{C} 19-\mathrm{C} 24$ of complex 2, respectively.

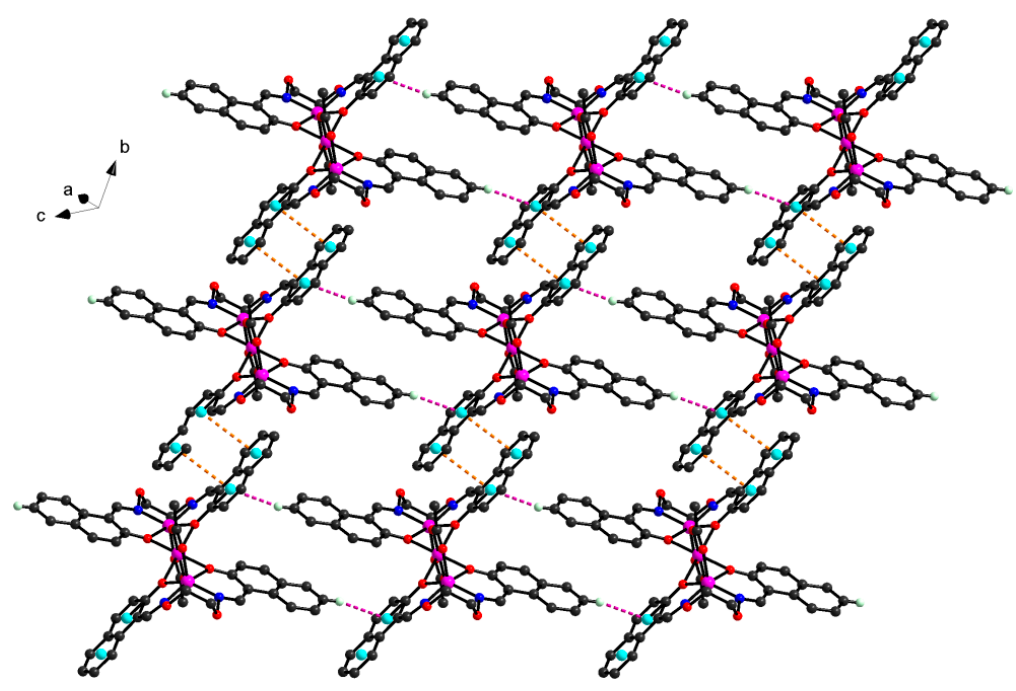

Figure 12. View of the 2D layered motif within 2 (hydrogen atoms, except those forming hydrogen bonds, are omitted for clarity).

\subsection{Anion Effects}

Obviously, coordination anions play an important part in the formation of the above different structures of $\mathrm{Co}$ (II) complexes. From the structure description, the free ligand $\mathrm{H}_{2} \mathrm{~L}$ presents very different coordination modes when different anions are involved in the coordination with $\mathrm{Co}$ (II) atoms. Complexes 1 and 2 were prepared in exactly the same way from a mixture of ligand $\mathrm{H}_{2} \mathrm{~L}$ with $\mathrm{Co}(\mathrm{Pic})_{2} \cdot 6 \mathrm{H}_{2} \mathrm{O}$ and $\mathrm{Co}(\mathrm{OAc})_{2} \cdot 4 \mathrm{H}_{2} \mathrm{O}$ in methanol solution, respectively, but the big structural differences in $\mathbf{1}$ and $\mathbf{2}$ suggest that the coordination anions indeed affect the ultimate structures of the assemblies: when the $\mathrm{Pic}^{-}$is involved in the coordination with $\mathrm{Co}(\mathrm{II})$ atoms, the mononuclear $[\mathrm{CoL}]$ unit, and the $\left[\mathrm{Co}(\mathrm{Pic})_{2}\left(\mathrm{CH}_{3} \mathrm{OH}\right)_{2}\right]$ unit in the $\mathrm{Co}(\mathrm{II})$ complex 1 with distorted square-planar and 
slightly distorted octahedron coordination polyhedron formed, respectively. Meanwhile, the OAc ${ }^{-}$ involved in the coordination with $\mathrm{Co}(\mathrm{II})$ atoms resulted in a trinuclear structure with the acetate ions coordinated to three $\mathrm{Co}$ (II) atoms through $\mathrm{Co}-\mathrm{O}-\mathrm{C}-\mathrm{O}-\mathrm{Co}$ bridges, possessing two distorted square pyramidal and an octahedral geometry around the central $\mathrm{Co}(\mathrm{II})$ atom. As a unique structure of the tetradentate coordination environment of $\mathrm{N}_{2} \mathrm{O}_{2}$, Salamo-type ligands have very good coordination ability. However, for some of the transition metals, the coordination still has some limitations, thus counter anions can easily coordinate with metal ions. In this article, the $\mathrm{Pic}^{-}$in complex $\mathbf{1}$ has a larger volume which has a hard coordination with metal ions. While, the $\mathrm{OAc}^{-}$in 2 has less steric hindrance than $\mathbf{1}$, it can easily coordinate to metal ions acting as a second ligand.

\section{Conclusions}

In summary, we successfully assembled and well characterized two novel Co(II) complexes of Salamo-type ligands. The results presented herein indicate that the coordination anions have a remarkable influence on the structures, coordination geometries, and supramolecular structures of the resulting complexes: when the $\mathrm{Pic}^{-}$is involved in the coordination with $\mathrm{Co}$ (II) atoms, a stable $\mathrm{Co}(\mathrm{II})$ complex contains the mononuclear [CoL] unit and the $\left[\mathrm{Co}(\mathrm{Pic})_{2}\left(\mathrm{CH}_{3} \mathrm{OH}\right)_{2}\right]$ unit with a 3D supramolecular network structure linked by $\mathrm{C}-\mathrm{H} \cdots \mathrm{O}$ hydrogen bonds and $\pi \cdots \pi$ stacking interaction. Meanwhile $\mathrm{OAc}^{-}$involved in the Co(II) complex resulted in a trinuclear structure with a 2D-layer supramolecular structure linked by $\mathrm{C}-\mathrm{H} \cdots \pi$ and $\pi \cdots \pi$ stacking interactions. These results may provide us with an interesting insight into how the assembly of $\mathrm{Co}$ (II) coordination compounds is affected by the coordination anions.

Acknowledgments: This work was supported by the National Natural Science Foundation of China (21361015) and the Outstanding Research Platform (Team) of Lanzhou Jiaotong University, which is gratefully acknowledged.

Author Contributions: All authors contributed to the writing and production of this manuscript.

Conflicts of Interest: The authors declare no competing financial interests.

\section{References}

1. Akine, S.; Taniguchi, T.; Nabeshima, T. Cooperative formation of trinuclear zinc(II) complexes via complexation of a tetradentate oxime chelate ligand, salamo, and zinc(II) acetate. Inorg. Chem. 2004, 43, 6142-6144. [CrossRef] [PubMed]

2. Dong, W.K.; Zheng, S.S.; Zhang, J.T.; Zhang, Y.; Sun, Y.X. Luminescent properties of heterotrinuclear 3d-4f complexes constructed from a naphthalenediol-based acyclic bis(salamo)-type ligand. Spectrochim. Acta Part A 2017, 184, 141-150. [CrossRef] [PubMed]

3. Tao, C.H.; Ma, J.C.; Zhu, L.C.; Zhang, Y.; Dong, W.K. Heterobimetallic 3d-4f Zn(II)-Ln(III) (Ln = Sm, Eu, $\mathrm{Tb}$ and $\mathrm{Dy}$ ) complexes with a $\mathrm{N}_{2} \mathrm{O}_{4}$ bisoxime chelate ligand and a simple auxiliary ligand Py: Syntheses, structures and luminescence properties. Polyhedron 2017, 128, 38-45. [CrossRef]

4. Wang, L.; Ma, J.C.; Dong, W.K.; Zhu, L.C.; Zhang, Y. A novel self-assembled nickel(II)-cerium(III) heterotetranuclear dimer constructed from $\mathrm{N}_{2} \mathrm{O}_{2}$-type bisoxime and terephthalic acid: Synthesis, structure and photophysical properties. Z. Anorg. Allg. Chem. 2016, 642, 834-839. [CrossRef]

5. Dong, Y.J.; Dong, X.Y.; Dong, W.K.; Zhang, Y.; Zhang, L.S. Three asymmetric salamo-type copper(II) and cobalt(II) complexes: Syntheses, structures, fluorescent properties. Polyhedron 2017, 123, 305-315. [CrossRef]

6. Li, L.H.; Dong, W.K.; Zhang, Y.; Akogun, S.F.; Xu, L. Syntheses, structures and catecholase activities of homo-and hetero-trinuclear cobalt(II) complexes constructed from an acyclic naphthalenediol-based bis(salamo)-type ligand. Appl. Organomet. Chem. 2017. [CrossRef]

7. Wu, H.L.; Pan, G.L.; Wang, H.; Wang, X.L.; Bai, Y.C.; Zhang, Y.H. Study on synthesis, crystal structure, antioxidant and DNA-binding of mono-, di- and poly-nuclear lanthanides complexes with bis(N-salicylidene)-3-oxapentane-1,5-diamine. J. Photochem. Photobiol. B 2014, 135, 33-43. [CrossRef] [PubMed] 
8. Wu, H.L.; Bai, Y.C.; Zhang, Y.H.; Li, Z.; Wu, M.C.; Chen, C.Y.; Zhang, J.W. Synthesis, crystal structure, antioxidation and DNA-binding properties of a dinuclear copper(II) complex with bis(N-salicylidene)-3-oxapentane-1,5-diamine. J. Coord. Chem. 2014, 67, 3054-3066. [CrossRef]

9. Wu, H.L.; Pan, G.L.; Bai, Y.C.; Wang, H.; Kong, J. Synthesis, structure, antioxidation, and DNA-bindingstudies of a binuclear ytterbium(III) complex with bis(N-salicylidene)-3-oxapentane-1,5-diamine. Res. Chem. Intermed. 2015, 41, 3375-3388. [CrossRef]

10. Chen, C.Y.; Zhang, J.W.; Zhang, Y.H.; Yang, Z.H.; Wu, H.L.; Pana, G.L.; Bai, Y.C. Gadolinium(III) and dysprosium(III) complexes with a schiff base bis( $N$-salicylidene)-3-oxapentane-1,5-diamine: Synthesis, characterization, antioxidation, and DNA-binding studies. J. Coord. Chem. 2015, 68, 1054-1071. [CrossRef]

11. Song, X.Q.; Cheng, G.Q.; Liu, Y.A. Enhanced Tb(III) luminescence by $\mathrm{d}^{10}$ transition metal coordination. Inorg. Chim. Acta 2016, 450, 386-394. [CrossRef]

12. Zhao, L.; Wang, L.; Sun, Y.X.; Dong, W.K.; Tang, X.L.; Gao, X.H. A supramolecular copper(II) complex bearing salen-type bisoxime ligand: Synthesis, structural characterization, and thermal property. Synth. React. Inorg. Metal-Org. Nano-Met. Chem. 2012, 42, 1303-1308. [CrossRef]

13. Zhao, L.; Dong, X.T.; Chen, Q.; Zhao, J.X.; Wang, L. Synthesis, crystal structure and spectral properties of a 2D supramolecular copper(II) complex with 1-(4-\{[(E)-3-ethoxyl-2-hydroxybenzylidene] amino\} phenyl) ethanone oxime. Synth. React. Inorg. Metal-Org. Nano-Met. Chem. 2013, 43, 1241-1246. [CrossRef]

14. Wang, P.; Zhao, L. Synthesis, structure and spectroscopic properties of the trinuclear cobalt(II) and nickel(II) complexes based on 2-hydroxynaphthaldehyde and bis(aminooxy) alkane. Spectrochim. Acta Part A 2015, 135, 342-350. [CrossRef] [PubMed]

15. Dong, W.K.; Lan, P.F.; Zhou, W.M.; Zhang, Y. Salamo-type trinuclear and tetranuclear cobalt(II) complexes based on a new asymmetry salamo-type ligand: Syntheses, crystal structures, and fluorescence properties. J. Coord. Chem. 2016, 69, 1272-1283. [CrossRef]

16. Dong, W.K.; Ma, J.C.; Zhu, L.C.; Zhang, Y.; Li, X.L. Four new nickel(II) complexes based on an asymmetric salamo-type ligand: Synthesis, structure, solvent effect and electrochemical property. Inorg. Chim. Acta 2016, 445, 140-148. [CrossRef]

17. Song, X.Q.; Liu, P.P.; Liu, Y.A.; Zhou, J.J.; Wang, X.L. Two dodecanuclear heterometallic $\left[Z_{6} \operatorname{Ln}_{6}\right]$ clusters constructed by a multidentate salicylamide salen-like ligand: Synthesis, structure, luminescence and magnetic properties. Dalton. Trans. 2016, 45, 8154-8163. [CrossRef] [PubMed]

18. Dong, W.K.; Ma, J.C.; Zhu, L.C.; Sun, Y.X.; Zhang, Y. A series of heteromultinuclear zinc(II)-lanthanide(III) complexes based on 3-MeOsalamo: Syntheses, structural characterizations, and luminescent properties. Cryst. Growth Design 2016, 16, 6903-6915. [CrossRef]

19. Dong, W.K.; Ma, J.C.; Zhu, L.C.; Zhang, Y. Nine self-assembled nickel(II)-lanthanide(III) heterometallic complexes constructed from a salamo-type bisoxime and bearing a N- or O-donor auxiliary ligand: Syntheses, structures and magnetic properties. New J. Chem. 2016, 40, 6998-7010. [CrossRef]

20. Liu, P.P.; Wang, C.Y.; Zhang, M.; Song, X.Q. Pentanuclear sandwich-type Zn ${ }^{\mathrm{II}}$-Ln ${ }^{\mathrm{III}}$ clusters based on a new salen-like salicylamide ligand: Structure, near-infrared emission and magnetic properties. Polyhedron 2017, 129, 133-140. [CrossRef]

21. Liu, Y.A.; Wang, C.Y.; Zhang, M.; Song, X.Q. Structures and magnetic properties of cyclic heterometallic tetranuclear clusters. Polyhedron 2017, 127, 278-286. [CrossRef]

22. Dong, W.K.; Akogun, S.F.; Zhang, Y.; Sun, Y.X.; Dong, X.Y. A reversible "turn-on" fluorescent sensor for selective detection of $\mathrm{Zn}^{2+}$. Sens. Actuators B 2017, 238, 723-734. [CrossRef]

23. Dong, W.K.; Li, X.L.; Wang, L.; Zhang, Y.; Ding, Y.J. A new application of Salamo-type bisoximes: As a relay-sensor for $\mathrm{Zn}^{2+} / \mathrm{Cu}^{2+}$ and its novel complexes for successive sensing of $\mathrm{H}^{+} / \mathrm{OH}^{-}$. Sens. Actuators $B$ 2016, 229, 370-378. [CrossRef]

24. Song, X.Q.; Liu, P.P.; Xiao, Z.R.; Li, X.; Liu, Y.A. Four polynuclear complexes based on a versatile salicylamide salen-like ligand: Synthesis, structural variations and magnetic properties. Inorg. Chim. Acta 2015, 438, 232-244. [CrossRef]

25. Liu, P.P.; Sheng, L.; Song, X.Q.; Xu, W.Y.; Liu, Y.A. Synthesis, structure and magnetic properties of a new one dimensional manganese coordination polymer constructed by a new asymmetrical ligand. Inorg. Chim. Acta 2015, 434, 252-257. [CrossRef] 
26. Yu, T.Z.; Zhang, K.; Zhao, Y.L.; Yang, C.H.; Zhang, H.; Qian, L.; Fan, D.W.; Dong, W.K.; Chen, L.L.; Qiu, Y.Q. Synthesis, crystal structure and photoluminescent properties of an aromatic bridged schiff base ligand and its zinc complex. Inorg. Chim. Acta 2008, 361, 233-240. [CrossRef]

27. Dong, X.Y.; Akogun, S.F.; Zhou, W.M.; Dong, W.K. Tetranuclear Zn(II) complex based on an asymmetrical salamo-type chelating ligand: Synthesis, structural characterization, and fluorescence property. J. Chin. Chem. Soc. 2017, 64, 412-419. [CrossRef]

28. Ma, J.C.; Dong, X.Y.; Dong, W.K.; Zhang, Y.; Zhu, L.C.; Zhang, J.T. An unexpected dinuclear Cu(II) complex with a bis(salamo) chelating ligand: Synthesis, crystal structure, and photophysical properties. J. Coord. Chem. 2016, 69, 149-159. [CrossRef]

29. Wang, B.J.; Dong, W.K.; Zhang, Y.; Akogun, S.F. A novel relay-sensor for highly sensitive and selective detection of $\mathrm{Zn}^{2+} / \mathrm{Pic}^{-}$and fluorescence on/off switch response of $\mathrm{H}^{+} / \mathrm{OH}^{-}$. Sens. Actuators B 2017, 247, 254-264. [CrossRef]

30. Dong, Y.J.; Li, X.L.; Zhang, Y.; Dong, W.K. A highly selective visual and fluorescent sensor for $\mathrm{Pb}^{2+}$ and $\mathrm{Zn}^{2+}$ and crystal structure of $\mathrm{Cu}^{2+}$ complex based-on a novel single-armed salamo-type bisoxime. Supramol. Chem. 2017, 29, 518-527. [CrossRef]

31. Dong, W.K.; Zhang, J.; Zhang, Y.; Li, N. Novel multinuclear transition metal(II) complexes based on an asymmetric salamo-type ligand: Syntheses, structure characterizations and fluorescent properties. Inorg. Chim. Acta 2016, 444, 95-102. [CrossRef]

32. Dong, W.K.; Zhang, J.T.; Dong, Y.J.; Zhang, Y.; Wang, Z.K. Construction of mononuclear copper(II) and trinuclear cobalt(II) complexes based on asymmetric Salamo-type ligands. Z. Anorg. Allg. Chem. 2016, 642, 189-196. [CrossRef]

33. Dong, W.K.; Zhang, L.S.; Sun, Y.X.; Zhao, M.M.; Li, G.; Dong, X.Y. Synthesis, crystal structure and spectroscopic properties of a supramolecular zinc(II) complex with $\mathrm{N}_{2} \mathrm{O}_{2}$ coordination sphere. Spectrochim. Acta Part A 2014, 121, 324-329. [CrossRef] [PubMed]

34. Akine, S.; Taniguchi, T.; Nabeshima, T. Synthesis and characterizationof novel ligands 1,2-bis(salicylideneaminooxy) ethanes. Chem. Lett. 2001, 30, 682-683. [CrossRef]

35. Dong, W.K.; Li, G.; Wang, Z.K.; Yong, D.X. A novel trinuclear cobalt(II) complex derived from an asymmetric salamo-type $\mathrm{N}_{2} \mathrm{O}_{3}$ bisoxime chelate ligand: Synthesis, structure and optical properties. Spectrochim. Acta Part A 2014, 133, 340-347. [CrossRef] [PubMed]

36. Dong, Y.J.; Ma, J.C.; Zhu, L.C.; Dong, W.K.; Zhang, Y. Four 3d-4f heteromultinuclear zinc(II)-lanthanide(III) complexes constructed from a distinct hexadentate $\mathrm{N}_{2} \mathrm{O}_{2}$-type ligand: syntheses, structures and photophysical properties. J. Coord. Chem. 2017, 70, 103-115. [CrossRef]

37. Dong, W.K.; Zhang, F.; Li, N.; Xu, L.; Zhang, Y.; Zhang, J.; Zhu, L.C. Trinuclear cobalt(II) and zinc(II) salamo-type complexes: Syntheses, crystal structures, and fluorescent properties. Z. Anorg. Allg. Chem. 2016, 642, 532-538. [CrossRef]

38. Dong, W.K.; Chen, X.; Sun, Y.X.; Yang, Y.H.; Zhao, L.; Xu, L.; Yu, T.Z. Synthesis, structure and spectroscopic properties of two new trinuclear nickel(II) clusters possessing solvent effect. Spectrochim. Acta. Part A 2009, 74, 719-725. [CrossRef] [PubMed]

39. Dong, W.K.; He, X.N.; Yan, H.B.; Lv, Z.W.; Chen, X.; Zhao, C.Y.; Tang, X.L. Synthesis, structural characterization and solvent effect of copper(II) complexes with a variational multidentate Salen-type ligand with bisoxime groups. Polyhedron 2009, 28, 1419-1428. [CrossRef]

40. Dong, W.K.; Sun, Y.X.; Liu, G.H.; Li, L.; Dong, X.Y.; Gao, X.H. Two supramolecular nickel(II) complexes: Syntheses, crystal structures and solvent effects. Z. Anorg. Allg. Chem. 2012, 638, 1370-1377. [CrossRef]

41. Dong, W.K.; Tong, J.F.; Sun, Y.X.; Wu, J.C.; Yao, J.; Gong, S.S. Studies on mono- and dinuclear bisoxime copper complexes with different coordination geometries. Transit. Met. Chem. 2010, 35, 419-426. [CrossRef]

42. Dong, W.K.; Wang, G.; Gong, S.S.; Tong, J.F.; Sun, Y.X.; Gao, X.H. Synthesis, structural characterization and substituent effects of two copper(II) complexes with benzaldehyde ortho-oxime ligands. Transit. Met. Chem. 2012, 37, 271-277. [CrossRef]

43. Dong, W.K.; Zhu, L.C.; Dong, Y.J.; Ma, J.C.; Zhang, Y. Mono, di and heptanuclear metal(II) complexes based on symmetric and asymmetric tetradentate Salamo-type ligands: Syntheses, structures and spectroscopic properties. Polyhedron 2016, 117, 148-154. [CrossRef] 
44. Dong, W.K.; Zhu, L.C.; Ma, J.C.; Sun, Y.X.; Zhang, Y. Two novel mono-and heptanuclear Ni(II) complexes constructed from new unsymmetric and symmetric salamo-type bisoximes-synthetic, structural and spectral studies. Inorg. Chim. Acta 2016, 453, 402-408. [CrossRef]

45. Sun, Y.X.; Li, C.Y.; Yang, C.J.; Zhao, Y.Y.; Guo, J.Q.; Yu, B. Two Cu(II) complexes with Schiff base ligands: Synthesis, crystal structure, spectroscopic properties, and substituent effect. Chin. J. Inorg. Chem. 2016, 32, 327-335.

46. Dong, W.K.; Duan, J.G.; Chai, L.Q.; Liu, G.L.; Wu, H.L. Synthesis and structural characterization of new trinuclear cobalt(II) and nickel(II) complexes possessing five- and six-coordinated geometry. J. Coord. Chem. 2008, 61, 1306-1315. [CrossRef]

47. Sun, Y.X.; Wang, L.; Dong, X.Y.; Ren, Z.L.; Meng, W.S. Synthesis, characterization, and crystal structure of a supramolecular $\mathrm{Co}^{\mathrm{II}}$ complex containing Salen-type bisoxime. Synth. React. Inorg. Metal-Org. Nano-Metal Chem. 2013, 43, 599-603. [CrossRef]

48. Dong, W.K.; Ma, J.C.; Dong, Y.J.; Zhu, L.C.; Zhang, Y. Di-and tetranuclear heterometallic 3d-4f cobalt(II)-lanthanide(III) complexes derived from a hexadentate bisoxime: Syntheses, structures and magnetic properties. Polyhedron 2016, 115, 228-235. [CrossRef]

49. Sun, Y.X.; Zhang, S.T.; Ren, Z.L.; Dong, X.Y.; Wang, L. Synthesis, characterization, and crystal structure of a new supramolecular $\mathrm{Cd}^{\mathrm{II}}$ complex with halogen-substituted Salen-type bisoxime. Synth. React. Inorg. Metal-Org. Nano-Metal Chem. 2013, 43, 995-1000. [CrossRef]

50. Dong, W.K.; Duan, J.G.; Guan, Y.H.; Shi, J.Y.; Zhao, C.Y. Synthesis, crystal structure and spectroscopic behaviors of $\mathrm{Co}(\mathrm{II})$ and $\mathrm{Cu}(\mathrm{II})$ complexes with Salen-type bisoxime ligands. Inorg. Chim. Acta 2009, 362, 1129-1134. [CrossRef]

51. Percy, G.C.; Thornton, J. Infrared spectra of $N$-aryl salicylaldimine complexes substituted in both aryl rings. J. Inorg. Nucl. Chem. 1973, 35, 2319-2327. [CrossRef]

52. Wu, H.L.; Wang, C.P.; Wang, F.; Peng, H.P.; Zhang, H.; Bai, Y.C. A new manganese(III) complex from bis(5-methylsalicylaldehyde)-3-oxapentane-1,5-diamine: Synthesis, characterization, antioxidant activity and luminescence. J. Chin. Chem. Soc. 2015, 62, 1028-1034. [CrossRef]

53. Wu, H.L.; Zhang, J.W.; Zhang, Y.H.; Chen, C.Y.; Li, Z.; Wu, M.C.; Yang, Z.H. Syntheses, crystal structures, electrochemical studies, and antioxidant activities of zinc(II) and copper(II) complexes with bis(2-benzimidazolyl) aniline derivatives. J. Coord. Chem. 2015, 68, 835-847. [CrossRef]

54. Chai, L.Q.; Huang, J.J.; Zhang, H.S.; Zhang, Y.L.; Zhang, J.Y.; Li, Y.X. An unexpected cobalt(III) complex containing a Schiff base ligand: Synthesis, crystal structure, spectroscopic behavior, electrochemical property and SOD-like activity. Spectrochim. Acta A 2014, 131, 526-533. [CrossRef] [PubMed]

55. Xu, L.; Zhu, L.C.; Ma, J.C.; Zhang, Y.; Zhang, J.; Dong, W.K. Syntheses, structures and spectral properties of mononuclear $\mathrm{Cu}^{\mathrm{II}}$ and dimeric $\mathrm{Zn}^{\mathrm{II}}$ complexes based on an asymmetric Salamo-type $\mathrm{N}_{2} \mathrm{O}_{2}$ ligand. Z. Anorg. Allg. Chem. 2015, 641, 2520-2524. [CrossRef]

56. Liang, Y.H.; Zhang, J.G.; Cui, Y.; Zhang, T.L.; Zhou, Z.N.; Yang, L. Two novel nitrogen-rich energetic coordination compounds $\mathrm{M}_{2}(\mathrm{DAT})_{5}\left(\mathrm{H}_{2} \mathrm{O}\right)_{3}(\mathrm{TNR})_{2}(\mathrm{M}=\mathrm{Zn}$ and $\mathrm{Co})$ : Synthesis, characterization, thermal properties and sensitivity. Chin. J. Struct. Chem. 2012, 31, 327-338.

57. Wu, B.D.; Zhang, T.L.; Yang, L.; Zhang, J.G.; Zhou, Z.N. Preparation, Crystal Structure, and Thermal Decomposition of the Energetic Compound $\left[\mathrm{Co}(\mathrm{IMI})_{4}(\mathrm{PA})\right](\mathrm{PA})(\mathrm{IMI}=$ Imidazole and PA = Picrate). Z. Anorg. Allg. Chem. 2013, 639, 163-168. [CrossRef]

58. Wu, H.L.; Liu, B.; Kou, F.; Jia, F.; Yuan, J.K.; Bai, Y. Cobalt(II) Complex with a Tridentate N Donor Ligand: Synthesis, Crystal Structure, Antioxidation, and DNA Binding Studies. Z. Anorg. Allg. Chem. 2012, 638, 122-128. [CrossRef]

59. Wu, H.L.; Shi, F.R.; Wang, X.L.; Zhang, Y.H.; Bai, Y.C.; Kong, J.; Wang, C.P. Synthesis, crystal structures, antioxidant activities and DNA-binding studies of two manganese(II) complexes with 1,3-bis(1-ethylbenzimidazol-2-yl)-2-oxopropane ligands. Transit. Met. Chem. 2014, 39, 261-270. [CrossRef]

(C) 2017 by the authors. Licensee MDPI, Basel, Switzerland. This article is an open access article distributed under the terms and conditions of the Creative Commons Attribution (CC BY) license (http:/ / creativecommons.org/licenses/by/4.0/). 